\title{
Koncept Maffie jako státotvorné komponenty v kolektivní paměti meziválečné československé společnosti
}

\section{The idea of the Maffia as a state-forming component in the collective memory of interwar Czechoslovak society}

Jan Hálek / halek@mua.cas.cz

Masarykův ústav a Archiv Akademie věd České republiky, v. v. i., Praha, CZ

\begin{abstract}
This study looks at issues related to using the concept of the so-called Maffia as representing the anti-Austrian Czech local resistance in the collective memory of interwar Czechoslovakia. Thus far the overwhelming majority of academic historical works have concentrated on the activities of the Maffia during the First World War. However, in this contribution the author examines the second life of this group when he looks for answers to questions concerning the origins of this group's name, who belonged to it, and the presentation and perception of the Maffia's activities in the public sphere in interwar Czechoslovakia.
\end{abstract}

\section{Keywords}

Maffia, home resistance, foreign resistance, First Czechoslovak Republic, collective memory

Studie vznikla v rámci řešení grantového projektu Grantové agentury ČR: č. 16-11252S „Maffie - mýtus a realita. Formování obrazu domácího protirakouského odboje v kolektivní paměti meziválečného Československa". 
Pro reflexi činnosti skupiny účastníků českého domácího protirakouského odboje, označované jako Maffie, je v literatuře odborného, encyklopedického i popularizačního charakteru typické zužování úhlu pohledu, z něhož je jednání těchto osob hodnoceno. Dodnes je základní výzkum a interpretace aktivit Maffie zásadně poznamenán „politicko-heroizujícimi “1 a prohradně vyznívajícími publikacemi Milady Paulové, coby jejího prvního historiografa, ${ }^{2}$ pracemi zakladatele Archivu národního osvobození a posléze ředitele politicko-archivního oddělení a ředitele knihovny Památníku osvobození, maffisty Jaroslava Werstadta ${ }^{3}$ a memoárovými díly přímých účastníků popisovaných událostí. Nejčastěji přitom bývají citovány vzpomínkové práce Tomáše Garrigua Masaryka, Edvarda Beneše, Jana Hajšmana, Jaroslava Rošického či Jaroslava Kvapila. ${ }^{4}$

Po druhé světové válce, respektive po únoru 1948, se toto téma ocitlo mimo zájem české historické obce. Změnilo se i hodnocení sledovaných dějů. Zahraničnímu a domácímu odboji byla přisuzována a vyčítána buržoazní, protilidová a protisovětská politika. ${ }^{5}$ Výše uvedené práce na dané téma, vzniklé v meziválečném období, pak byly označovány jako subjektivní a stranické, jimiž se tehdejší „buržoazní a sociálšovinistické veličiny “ a historici snažili „smýt nebo zkrášlit své tehdejši jednáni“ “. ${ }^{6}$ Maffii, jako jednomu z aktérů československého protirakouského odboje, věnovali pozornost až autoři akademického Přehledu československých dějin (Maketa), vydaného v roce 1960. V souladu s tehdejšími historiografickými koncepty byla prezentována jako „hlavni ústredna české buržoazni špionážni služby ve prospěch Dohody“. Vedle výzvědné činnosti bylo Maffii přrisouzeno i ovlivňování vnitropolitického vývoje v českých buržoazních stranách a snaha vytvářet předpoklady pro zesílení vlivu západoevropských, buržoazně demokratických politických idejí na českou společnost. Tím zároveň měla působit coby protiváha „tradičních rusofilských nálad“, panujících mezi příslušníky české inteligence. Jako hlavní motivy, aktivizující vedoucí představitele odboje, byly uváděny jejich obavy z „jakékoliv revoluční změny“, která by mohla

1 Kubů, Eduard - Šouša, Jiří: T. G. Masaryk a jeho c. k. protivníci. Československá zahraniční akce ženevského období v zápase s rakousko-uherskou diplomacií, zpravodajskými službami a propagandou (1915-1916). Praha 2015, s. 10.

2 Nejčastěji jsou citovány následující tituly: Paulová, Milada: Dějiny Maffie. Odboj Čechů a Jihoslovanů za světové války 1914-1918. I. díl. Ve znaku persekuce. Praha 1937. Táž: Dějiny Maffie. Odboj Čechů a Jihoslovanů za světové války 1914-1918. II. díl. Maffie a politika česko-jihoslovanská, část první. Praha 1939.

3 Werstadt, Jaroslav: Politické plány české Maffie v proním roce války. Naše revoluce VI, 1929/1930, s. 369-427; VII, 1931, s. 292-423.

4 Masaryk, Tomáš Garrigue: Světová revoluce. Za války a ve válce 1914-1918. Praha 2005; Beneš, Edvard: Světová válka a naše revoluce. I-III. Praha 1927-1928; Hajšman, Jan: Česká mafie. Vzpomínky na odboj doma. Praha 1932; Týž: Mafie v rozmachu. Jak jsme bourali Rakousko. Praha 1933; Rošický, Jaroslav: Rakouský orel padá. Jak byla naše revoluce doma připravena a 28. ř́jjna 1918 provedena vojensky. Praha 1933; Kvapil, Jaroslav: $O$ čem vím. Sto kapitol o lidech a dějích z mého života. Praha 1932.

5 Na tento aspekt upozornil již v roce 1967 v jedné ze svých studií Jan Galandauer. Srov. Galandauer, Jan: Vztah Řínové revoluce a vzniku ČSR v československé historiografii po únoru 1948. Příspěvky k dějinám KSČ. Časopis pro dějiny KSČ a mezinárodního dělnického a komunistického hnutí 7, 1967, s. 201-226.

6 Křížek, Jurij - Řiha, Oldřich: Bez Velké řínové socialistické revoluce by nebylo Československa. Praha 1951; Šolle, Zdeněk: Dělnické hnuti v českých zemích za imperialistické světové války. Praha 1952. Srov. Galandauer, J.: Vztah Řínové revoluce a vzniku ČSR v československé historiografii po únoru 1948, s. 201-226. 
ohrozit zájmy buržoazie, kterou reprezentovali. Příslušní autoři přitom s pojmem Maffie čile operovali, přičemž její roli a význam sice schematizovali, ale nemarginalizovali. ${ }^{7}$

Oživení zájmu o problematiku, týkající se protirakouského odboje a vzniku československé republiky, můžeme pozorovat až v průběhu šedesátých let 20. století. Výsledkem byly zejména práce Milady Paulové a Karla Pichlíka. ${ }^{8}$ Práce Paulové přitom představuje další významný zdroj informací, týkajících se Maffie a její činnosti v letech 1916-1918. Následující období však rozpracování nastíněných témat ze strany československé historiografie nepřineslo a roli Maffie celkově spíše upozad’ovalo. Výraznější změna nenastala ani po roce 1989. Význam Maffie byl i nadále zpravidla interpretován především v intencích zmiňovaných prací Paulové a Pichlíka. ${ }^{9}$ Výjimku představují studie z pera Zdeňka Kárníka, pojednávající o možnostech a limitech spolupráce zahraničního a domácího odboje v posledních měsících první světové války, ${ }^{10}$ edice dokumentující zpravodajskou činnost Zdeňka Rohly a Josefa Jana Friče, připravená Martinem Kučerou, ${ }^{11}$ a některé pramenné edice a časopisecké studie publikované autorem tohoto článku, at již samostatně, či ve spolupráci s Danielou Brádlerovou. ${ }^{12}$

Obdobné tendence, jako v případě odborné historiografické produkce, můžeme pozorovat i na stránkách encyklopedií a slovníků. V roce 1929 bylo Maffii věnováno jedno z hesel Masarykova slovniku naučného. Maffie zde byla charakterizována jako tajné sdružení několika předních protirakouských českých politiků, jejichž hlavním úkolem bylo posilování mravního odporu proti Rakousku, informování vůdců československého zahraničního odboje Masaryka a Beneše a financování československého revolučního hnutí. O dva roky později následovalo rozsáhlé dvousloupcové pojednání v Ottově slovniku naučném nové doby. Jeho autorem byl přední maffista Antonín Hajn. Naopak Př́ručni slovnik naučný z roku 1966, stejně jako o dvacet let mladší Malá československá encyklopedie si již vystačily s prostým konstatováním, že se jednalo o tajnou organizaci vedenou českými buržoazními politiky, usilujícími o spojení domácího a zahraničního protirakouského

7 Přehled československých dějin. Díl II. 1848-1918. Svazek 2. 1900-1918. Praha 1960, s. 1152-1153.

8 Paulová, Milada: Tajný výbor [Maffie] a spolupráce s Jihoslovany v letech 1916-1918. Praha 1968; Pichlík, Karel: Zahranični odboj 1914-1918 bez legend. Praha 1968.

9 Srov. např. Šedivý, Ivan: Češi, české země a velká válka 1914-1918. Praha 2001, s. 177-190; Kárník, Zdeněk: České země v éře Proni republiky (1918-1938). I. Praha 2003, s. 17-37; Dejmek, Jindřich: Edvard Beneš. Politická biografie českého demokrata. Část první. Revolucionář a diplomat (1884-1935). Praha 2006, s. 117-214; Kubů, E. - Šouša, J.: T. G. Masaryk a jeho c. k. protivníci, passim; Marès, Antoine: Edvard Beneš od slávy k propasti. Drama mezi Hitlerem a Stalinem. Praha 2016, s. 42-87.

10 Kárník, Zdeněk: Edvard Beneš a Maffie v nejtěžšim obdobi Velké války. Řídila politická emigrace domácí odboj? (červenec 1917 - říjen 1918). Historie a vojenství 44, 1995, s. 3-22.

11 Zprávy tajným inkoustem. Kapitola z dějin českého zpravodajství za první světové války (1914-1918). Ed. M. Kučera. Praha 2003.

12 „Drahý pane kancléri... “Vzájemná korespondence Milady Paulové a Přemysla Šámala, I. díl (1921-1935), II. díl (1936-1939 [1945]). Eds. D. Brádlerová, - J. Hálek. Praha 2011-2012; Střet generací? Paměti a vzájemná korespondence zakladatelů české byzantologie a slovanských studií. Eds. D. Brádlerová - J. Hálek. Praha 2014; Americká stopa české Maffie. Vzájemná korespondence prvního československého vyslance v USA Bedřicha Štěpánka s kancléřem prezidenta republiky Přemyslem Šámalem (1921-1938). Ed. J. Hálek. Praha 2015; Hálek, Jan: Diplom pro Maffii. Časopis Národního muzea, řada historická 183, 2014, s. 49-64. Týž: Maffistév politickém životě prvorepublikového Československa (1919-1921) - role Přemysla Šámala. Historie - otázky - problémy 6, 2014, s. 147-156. 
odboje za první světové války. Naopak Všeobecná encyklopedie v osmi svazcích se v roce 1999 vrátila zpět ke zmíněným prvorepublikovým výkladům. ${ }^{13}$

Popularizační práce, týkající se Maffie, zcela pochopitelně akcentují především její zpravodajskou činnost. Pozornost je věnována zejména odbojovým aktivitám nesoucím určitý punc dobrodružnosti nebo romantiky, jako je otázka užíání šifer a neviditelných inkoustů či spojení mezi domovem a exilem prostřednictvím kurýrů. Opomíjena není ani tzv. knoflíková aféra, podíl Maffie na přípravách na vzniku republiky či její účast na událostech 28. října 1918. Ani tato literatura však nepřekračuje hranice vytyčené již zmíněnou dobovou memoárovou literaturou a pracemi Milady Paulové a Karla Pichlíka. ${ }^{14}$

Přestože se dosavadní bádání o Maffii zaměřovalo téměř výlučně na léta 1914-1918, jsem přesvědčen, že její význam toto období výrazně přesahuje. Nelze opomenout roli, kterou sehrála jako státotvorná komponenta, přispívající jako součást oficiální státní propagandy a ikonografie $\mathrm{k}$ formování kolektivního vědomí a paměti československé prvorepublikové společnosti. Z tohoto úhlu pohledu představuje Maffie už ne tak zcela jasný, ale naopak mnohovrstevnatý pojem, s nímž se pojí řada otázek, týkajících se vlastního pojmenování této skupiny, vymezení jejího personálního obsazení i prezentace a vnímání její činnosti ve veřejném prostoru meziválečného Československa.

\section{Maffie - nejasný a mnohovrstevnatý pojem}

Pojem Maffie je třeba autorsky a diskursivně ukotvit a vymezit s ním spojovanou skupinu osob. Opomenout nelze ani roli tohoto uskupení, coby jednoho z přesvědčovacích prostředků o jednotě a spolupráci českého domácího a zahraničního protirakouského odboje a o nutnosti další kooperace v rámci nového státu, v prvorepublikové kolektivní paměti. Při hledání počátku používání termínu Maffie vedou všechny stopy do období tzv. boje o rukopisy, kdy jako „Maffie“ či „literárni banditi“ byla ze strany obránců Rukopisů označována skupina př́ínivců T. G. Masaryka, shromážděných kolem časopisů Čas a Athaeneum. Ti toto označení s krajně negativní až pejorativní konotací, za jehož autora je označován vydavatel Národních listů Julius Grégr, přijali za své. ${ }^{15}$ Termín Maffie tak můžeme vnímat jako označení skupiny osob, podporujících veřejnou činnost a názorové směřování T. G. Masaryka. Z veřejného diskurzu se však patrně vytratilo společně s uklidněním rukopisných sporů. K jeho používání v době první světové války se v materiálech,

13 Masarykưv slovnik naučný. Lidová encyklopedie všeobecných vědomostí. Díl IV. Ko-M. Praha 1929, s. 650; Ottĩv slovník naučný nové doby. Dodatky k Velikému Ottovu slovníku naučnému. Díl I., svazek 2., Br-Dej. Praha 1931, s. 1096-1097 (v rámci hesla Československo); Př́ručni slownik naučný. III. díl. M-̌̌. Praha 1966, s. 12; Malá československá encyklopedie. IV. svazek. M-Pol. Praha 1986, s. 30; Všeobecná encyklopedie v osmi svazcich. Svazek 5, M-O. Praha 1999, s. 22.

14 Srov. napřs: Čada, Václav: 28. ř́jen 1918. Skutečnost, sny a iluze. Praha1988; Čechura, Jaroslav - Čechurová, Jana - Hlavačka, Milan - Koldinská, Marie: Historie českých spiknutí. Praha 2000, s. 132-142; Galandauer, Jan: Knoflik ze šatů pani Linhartové. Špionážní nehoda prvního odboje. Dějiny a současnost 30, 2008, s. 30-32; Pacner, Karel: Osudové okamžiky Československa. Praha 2012, s. 49-129; Lukeš, Michal: Špionážní př́pady. Praha 2016, s. 13-42.

15 Herben, Jan: Deset let proti proudu (1886-1896). Praha 1898, s. 92. 
které mi jsou známy, nikdo z účastníků odboje nehlásí. O Maffii se ostatně nehovoří ani v dochovaných materiálech dokumentujících domácí a zahraniční odboj, ani v písemnostech rakouské policie a ve vyšetřovacích spisech vedených proti účastníkům české rezistence. Po vzniku republiky však docházelo ke zcela záměrné a promyšlené institucionalizaci tohoto termínu, přičemž se nikdo ze zainteresovaných osob netajil tím, že se používání slova Maffie pro účastníky domácího odboje, spolupracující s Masarykovou a Benešovou zahraniční akcí, váže až ke konci války a vzniku Československa.

Kancléř prezidenta republiky Přemysl Šámal, který po odchodu Beneše do exilu fakticky stanul v čele domácího odboje a po vzniku nového státu byl označován jako pomyslná hlava Maffie, v prosinci 1931 na otázku Jaroslava Kvapila, jednoho ze svých nejbližších odbojových spolupracovníků, kdy se označení Maffie začalo v souvislosti s domácí protirakouskou rezistencí používat, vyslovil přesvědčení, že se jeho znovuoživení váže až ke konci války a k osobě redaktora Jana Herbena. ${ }^{16} \mathrm{~S}$ ohledem na skutečnost, že Herben byl v roce 1886 zakladatelem a v letech 1894-1906 i majitelem již zmíněného Času, kam přešel z Národních listů poté, co jej jejich majitel Julius Grégr za podporu odpůrců Rukopisů krátce předtím propustil, jeví se toto tvrzení jako značně pravděpodobné. K redakci Času směřuje i vzpomínka Josefa Záruby-Pfeffermanna. ${ }^{17}$ Jsem přesvědčen, že přestože Antonín Hajn ve výše zmíněném encyklopedickém heslu v roce 1931 tvrdil, že jméno Maffie bylo po válce zvoleno „zcela nahodile“, ${ }^{18}$ můžeme konstatovat, že se s největší pravděpodobností skutečně jednalo o revitalizaci termínu Maffie v jeho významu z doby rukopisných bojů. Význam tohoto označení přitom zůstával stále tentýž - skupina Masarykových názorových sympatizantů, podporovatelů a spolupracovníků. K institucionalizaci Maffie nepochybně přispěly práce již zmíněné historičky Milady Paulové, ${ }^{19}$ které vznikaly v úzké spolupráci a pod téměř nepřetržitým dohledem dvou výrazných představitelů Maffie, Přemysla Šámala a Bedřicha Štěpánka. ${ }^{20}$

16 Archiv Kanceláře prezidenta republiky, Praha (=AKPR), Kancelář prezidenta republiky - protokol T (=KPRT), sg. T 125/22 Maffie, část II, kart. 81, Interní záznam P. Šámala, 15. prosince 1931. Ve stejném duchu ostatně vyzněl již Šámalův fejeton, otištěný 22. prosince 1918 v souvislosti s návratem prezidenta Masaryka do Československa v Národnich listech, v němž se hovořilo o „nyni tak zvané Maffi “. Šámal, Přemysl: T. G. Masaryk za hranicemi (fejeton). Národní listy, 22. prosince 1918, č. 164, s. 1. V této souvislosti si zaslouží pozornost tvrzení Šámala a Antonína Hajna, že Maffie toto své označení používala již v srpnu 1917. Hajn, Antonín - Šámal, Přemysl: Před Národním výborem. In: Národní shromáždění československé v prvním roce republiky. Ročenka 1918-1919. Praha 1919, s. 8. Je možné, že označení Maffie pro sebe používal Š́malem vedený Tajný výbor.

17 Josef Záruba-Pfeffermann uváděl: „Kolektivni název přišel až po převratu. Já, který jsem byl při zrodu všech akcí a prolezl jsem všechny oficiální i neoficiálni spiklenecké kroužky, po největším úsili paměti, slyšel jsem to slovo Maffie ponejprv od Julia Schmidta, bývalého redaktora Času (tedy někoho, kdo rozhodně nebyl v prvni linii, eufemisticky řěeno), po převratu. “ Archiv Národního muzea, Praha (=ANM), MAFFIE Paulová Milada - Maffie, inv. č. 43, kart. 3, Korespondence s Josefem Zárubou-Pfeffermannem o vzniku a činnosti Maffie. Stejného názoru, jako všichni předchozí, byl i další z maffistů František Bělehrádek. Srov. Bělehrádek, František: Z maffiánských a jiných válečných vzpomínek. Naše revoluce VI, 1929/1930, s. 1.

18 Ottĩv slovnik naučný nové doby. Dodatky k Velikému Ottovu slovníku naučnému, Díl I. Svazek 2. Br-Dej. Praha 1931, s. 1096-1097.

19 Paulová, M.: Dějiny Maffie I-II; Táž: Jihoslovanský odboj a česká Maffie. Díl I.: Chorvatská politika za světové války do otevření ř́̌šské rady ve Vídni v květnu 1917 (1914-1917). Praha 1928.

20 „Drahý pane kancléři..." I, II, passim. Masarykův ústav a Archiv AV ČR, v. v. i. (=MÚA), Archiv Akademie 
Vedle vlastního ustavení Maffie jako instituce, symbolizující de facto domácí protirakouský odboj, bylo rovněž nezbytné vymezit její členskou základnu. Za tímto účelem bylo v průběhu let 1919-1929 vypracováno několik jmenných seznamů. Autorem většiny z nich byl již několikrát zmíněný Přemysl Šámal, zastávající od začátku roku 1919 úřad kancléře prezidenta republiky. První soupis byl vyhotoven u příležitosti oslav vzniku Československé republiky v ř́jjnu 1919. Obsahoval 71 jmen osob, které měly být pozvány na audienci na Pražský hrad..$^{21}$ Tablo členů Maffie, které o rok později vyhotovila pražská fotografická firma Drtikol a spol., publikované na stránkách Českého světa, představilo čtenářům tohoto časopisu 75 maffistů. ${ }^{22}$ Další Šámalovy seznamy z let 1922 a 1924 již zahrnovaly 90, respektive 95 jmen. ${ }^{23}$ Rok 1925 přinesl uznání a ocenění zásluh maffistů prostřednictvím udělení československé revoluční medaile. Místo aby slavnostní předání vyznamenání jejich nositelům, k němuž došlo 11. listopadu 1925, znamenalo definitivní uzavření této skupiny, následoval naopak další nárůst počtu osob hlásících se ke své maffistické minulosti. Podnětem k tomu byla výzva, aby se členové Maffie, na které snad omylem bylo zapomenuto, obrátili na Ministerstvo národní obrany, které mělo po provedení př́íslušného šetření rozhodnout o případném dodatečném udělení vyznamenání. ${ }^{24} \mathrm{~V}$ důsledku toho evidovalo ministerstvo v červnu 1928 již celkem 126 osob s uznanou maffistickou minulostí. ${ }^{25}$ Mezi nimi bychom nalezli rovněž skupinu téměř dvou desítek mužů, označovanou jako Vojenská Maffie. ${ }^{26} \mathrm{~S}$ ohledem na skutečnost, že se jednotlivé seznamy zcela neshodují a jiné pramenné zdroje okruh jmen spojovaných s Maffií ještě více rozšiřují, pohybuje se skutečný počet osob, označovaných jako maffisté, okolo čísla 200.

Vlastní jádro Maffie, označované někdy jako Tajný výbor, představovali muži, kteří v době první světové války byli ve spojení s Masarykovou a Benešovou akcí a snažili se o těsnou kooperaci s ní. Jako užší politické grémium Maffie bývá označován úzký okruh osob: Edvard Beneš, Karel Kramář, Alois Rašín, Josef Scheiner, Přemysl Šámal. Po zatčení Kramáře a Rašína, k němuž došlo v květnu a červenci 1915, krátkém věznění Scheinera v květnu až červenci téhož roku a po odchodu Beneše do exilu v prvních záři-

věd ČR (=A AV ČR), Milada Paulová, inv. č. 815, sg. III g, kart. 34, Poznámky B. Štěpánka ke vznikajícímu rukopisu Dějin Maffie. K osobě Bedřicha Štěpánka: Hálek, Jan: Bedřich Štěpánek. Nepohodlný muž československé diplomacie. Praha 2017.

21 AKPR, Kancelář prezidenta republiky 1919-1947 (=KPR), inv. č. 559, sg. D 4382, kart. 46. Seznam členů Maffie pozvaných na audienci 28. ř́ijna 1919.

22 Český svět, roč. XVI, č. 29, 25. března 1920, s. 39.

23 MÚA, Archiv Ústavu T. G. Masaryka, EB I Edvard Beneš, inv. č. 1257, sg. R 178/18, kart. 254, Seznam členů Maffie (1922), vyhotoveno P. Šámalem; AKPR, Přemysl Šámal, sg. 41/1924, kart. 38, Seznam členů Maffie vyhotovený P. Śámalem jako podklad pro výběr osob zvaných na čaje na Pražský hrad, 17. ledna 1924.

24 Hálek, J.: Diplom pro Maffii, s. 60-63.

25 Vojenský ústřední archiv - Vojenský historický archiv, Praha, MNO Ministerstvo národní obrany 19181939, inv. č. 12374, sg. 90 1/17, kart. 7374, Seznam členů Maffie vyznamenaných čs. revoluční medailí - Zpráva MNO senátoru F. Soukupovi, 25. června 1928. 
jových dnech 1915 jsou jako jádro Maffie prezentováni Jaroslav Kvapil, Bohuslav Franta, Antonín Hajn a Bedřich Štěpánek v čele s Přemyslem Šámalem. ${ }^{27}$

Sledujeme-li personální složení Maffie, můžeme konstatovat, že mezi jejími členy a spolupracovníky byli zastoupeni zejména zástupci středních a vyšších společenských vrstev. Jednalo se převážně o reprezentanty domácí politiky, kteří se různými způsoby vyslovili pro myšlenku spolupráce s exilem. Nalezneme mezi nimi mladočechy, národní sociály, státoprávníky, sociální demokraty a do určité míry i agrárníky. Vedle politiků se mezi maffisty setkáme často také s profesně a společensky etablovanými osobami. V řadě případi̊ přitom šlo o hmotně zajištěné jedince. Ve výčtu maffistů nescházelo ani několik žen. Jednalo se zpravidla o manželky v Maffii zaangažovaných mužů. Národnostně představovala Maffie téměř výlučně českou společnost. Jako výjimky můžeme uvést Slováky Ivana Dérera, Antona Štefánka a Vavro Šrobára. Členové Maffie působili především v Praze. Nescházely zde však ani venkovské kontakty. Spojení s Novým Bydžovem tak např. zprostředkovával Oskar Butter, s Mělníkem Václav Petrželka, s Benešovem František Veselý, s oblastí Kouřimska molitorovský velkostatkář Jaroslav Veselý. Plzeň byla s Maffií propojena osobami Karla Hepnera, Arnošta Rosy a dalšími. Kontakty s Brnem zajištoval redaktor Lidových novin Arnošt Heinrich.

Jako politické pozadí celé akce bývají uváděni lidé typu předsedy agrárníků Antonína Švehly, kteří ve svém jednání pokyny zahraničního odboje rovněž zohledňovali. Ve svých činech se však jimi ne vždy cítili být vázáni. Podle vzpomínek Bohuslava Franty šéf agrárníků „lavíroval“ a „nechtěl si pálit prsty“. „Jednal mazaně [...]. Jini měli nůž na krku - Švehla ho neměl. "28 Toto chování mělo za následek jistou nedůvěru, projevovanou ze strany některých maffistů vůči jeho osobě. Zatímco Šámal po válce hodnotil svůj vztah k předsedovi agrárníků jako „velmi nesrdečny “29 a podle Frantových vzpomínek v době války velmi zvažovali, které informace je bezpečné Švehlovi svěřit, ${ }^{30}$ byl názor dalšího z okruhu spiklenců, molitorovského velkostatkáře Jaroslava Veselého, výrazně příznivější, když konstatoval: „Švehla nebyl ani co by se za nehet vešlo menším vlastencem nežli ostatni členové Maffie, ale mèl dưvody, aby své smýšleni až do určité doby nestavěl veřejně na odiv. "31 Další z maffistů, někdejší redaktor Času Jan Hajšman, ve svých vzpomínkách Švehlovu pozici charakterizoval takto: „Vidal jsem tam [...] mnoho takových, kteři jinak se neshodli než v Švehlově čekárně. [...] aktivisté, rakušáci, radikálové, spiklenci, když od Švehly odcházeli, všichni se stejně spokojenĕ usmívali; jeden si pobrukoval Zachovej nám, Hospodine, druhý notoval do vousů nápěv carské hymny. Všichni odcházeli přesvědčeni, že u Švehly pochodili, že je Švehla jejich člověk. Bylo mi jasno, že Švehla jakousi neviditelnou mašinerii a tajemně cosi vede; kam, to věděl asi jen on sám. Ale vedl tak, že ti druzi, kteři s nim šli, byli pevně přesvědčeni, že vedou oni a byli spokojeni. “32

27 Paulová, M.: Dějiny Maffie II/1, s. 11.

28 ANM, Hn 6 Bohuslav Franta, kart. 1, Poznámky k dění v první světové válce.

29 ANM, Přemysl Šámal, inv. č. 135, kart. 2, Záznam rozhovoru M. Paulové s P. Šámalem o sestavování první československé vlády v roce 1918, 12. února 1934.

30 ANM, Hn 6, kart. 1, Poznámky k dění v první světové válce.

31 Srov. ANM, MAFFIE, inv. č. 41, kart. 3, Jaroslav Veselý, Ještě hrst vzpomínek na Antonína Švehlu.

32 Hajšman, J: Mafie v rozmachu, s. 134. Srov. Dostál, Vladimír: Antonín Švehla. Profil československého státníka. Praha 1990, s. 37-65. 
Bud' jak bud', Švehlovo jméno figurovalo i v soupisu členů Maffie, pozvaných 28. října 1919 k audienci u prezidenta Masaryka na Pražský hrad. ${ }^{33}$

Po skončení války se aktivity maffistů neomezovaly pouze na vzájemnou přátelskou spolupráci. Přinejmenším v první polovině dvacátých let 20. století hrála Maffie v celospolečenském měřítku důležitou roli. Její potenciál vlivné instituce se značným morálním kreditem, respektovaným ze strany většiny české veřejnosti, dokládá i existence tzv. čestného soudu Maffie. V této souvislosti je nejznámějším případ hudebního skladatele, houslisty a zakladatele Českého kvarteta Josefa Suka, kterého krátce po 28. ř́ijnu 1918 obvinil z prorakouského aktivismu hudební vědec a kritik Zdeněk Nejedlý. Obžaloba byla záhy rozšířena i na osobu dalšího člena kvarteta, Karla Hoffmanna.

Oba umělci požádali v této situaci Maffii o vyslovení stanoviska, zda se skutečně provinili proti zájmům českého národa. V rámci čestného soudu se záležitostí zabývali Bohuslav Franta, Josef Jan Frič, Antonín Hajn, Josef Svatopluk Machar, Jaroslav Kvapil, Josef Scheiner, Bedřich Štěpánek a Přemysl Šámal. Na Sukovu stranu se neváhal postavit ani Jan Herben. Maffisté Nejedlého útok shledali jako nepřiměřený a konstatovali, že se jedná o krok vyvolaný Nejedlého osobní animozitou. Při svém rozhodování byli podpořeni provoláním 56 významných osobností uměleckého a vědeckého života. ${ }^{34}$

Sukův případ nebyl jediným, v němž byla Maffie žádána o zaujmutí stanoviska. Jako další můžeme zmínit kauzy bývalého aprovizačního ředitele pražských jatek Adolfa Bergmana, ${ }^{35}$ někdejšího rakouského ministra obchodu a sympatizanta Maffie Josefa Fořta ${ }^{36}$ či dalšího hudebníka, skladatele Oskara Nedbala. Reakce veřejnosti na maffistická vyjádření však nebyly vždy pouze souhlasné. Již v Sukově kauze se na stranu Nejedlého postavili například filozofové František Krejčí a Emanuel Rádl. Druhý jmenovaný neváhal označit aktivity Machara a Herbena podnikané v Sukův prospěch za trapné, když dodával: „Aspoň tolik by ti pánové měli vidět, že tímto projevem nejen že dávaji amnestii všem válečným lumpưm, nýbrž zakřikuji každého, kdo by proti nim něco řekl, označujice jeho za lumpa a ty lidi za čestné muže. To je prostě strašné. "37 Maffisté si však sami dobře uvědomovali, že nejsou oprávněni působit nadále jako samozvaný soudní tribunál, a jejich přístup k dalším kauzám již byl výrazně opatrnější, přičemž Oskar Nedbal narazil ve své záležitosti na odmítnutí. Továrník Frič v této souvislosti vyjádřil obavu, že by zatažením do Nedbalovy aféry mohlo být jméno Maffie „silně diskreditováno “. 38

Postoj takto angažovaných př́íslušníků Maffie se ukázal jako vcelku rozvážný, v otázkách klíčových pro vnitropolitickou a společenskou atmosféru v mladé republice pak

33 AKPR, KPR 1919-1947, inv. č. 559, sg. D 4382, kart. 46, Seznam členů Maffie pozvaných na audienci 28. ř́ijna 1919.

34 Křestan, Jiří: Zdeněk Nejedlý. Politik a vědec v osamění. Praha 2012, s. 142-145. Srov. např.: Národní politika, 30. ledna 1919, č. 29; Právo lidu, 30. ledna 1919, č. 26.

35 ANM, Antonín Hajn, inv. č. 1731, kart. 31, P. Šámal A. Hajnovi, 4. července a 30. ř́ijna 1919.

36 AKPR, Přemysl Šámal, sg. 123/1921, kart. 10, J. Fořt P. Šámalovi, 7. července 1920; P. Šámal J. Fořtovi, 15. července 1920; Interní záznam P. Šámala, 21. března 1921.

37 A AV ČR, ZN Zdeněk Nejedlý, osobní korespondence, kart. 51, E. Rádl Z. Nejedlému, 16. února 1919.

38 AKPR, Přemysl Šámal, sg. 74/1921, kart. 10, J. J. Frič P. Šámalovi, 15. ledna 1920; P. Šámal J. J. Fričovi, 21. ledna 1920. 
dokonce jako obratný až konstruktivní. Bylo v zájmu vznikajícího státu uklidňovat vášně, nepochybně doutnající uvnitř české společnosti. Žádoucí bylo rovněž zajištění klidného administrativního přechodu z podmínek monarchie. V tomto duchu vyznívala i vyjádření některých maffistů. Uvést můžeme například Jana Herbena, který konstatoval: „Všichni jsme lhali. [...] Rakušany jsme byli až do 28. řína 1918. "99 Podobně vyznívala i vyjádření z pera Josefa Svatopluka Machara, který napsal: „Nejděmež kupředu s hlavou otočenou vzad. Kde možno odpustit, odpusṫme, kde možno zapomenout, zapomeňme. Táhneme všichni za jeden provaz, chceme všichni upevněni naši republiky, chceme klid bez otřesü. "40

Důsledně vytvářený maffistický narativ byl v rámci české meziválečné společnosti velmi ochotně akceptován, přičemž nezůstával omezený pouze na osoby jmenované v oficiálních seznamech členů Maffie. Snahu o sebeidentifikaci s ním lze nepochybně s úspěchem hledat i v případě některých profesních uskupení. Doloženy máme zmínky o existenci technicke $e^{41}$ či profesorské maffie. ${ }^{42}$ Ve své podstatě se jednalo o skupiny osob, propojených svým zaměstnáním a přátelskými vazbami, které se s blížícím se koncem první světové války začaly zabývat otázkami, souvisejícími s možnostmi poválečné obnovy českých zemí. Vznik těchto společenství s činností Maffie, vedené Přemyslem Šámalem, s největší pravděpodobností přímo nesouvisel. Její vliv však zcela vyloučit nelze. Tím spíše, že technická maffie, shromážděná kolem pozdějšího zakladatele Masarykovy akademie práce, inženýra Stanislava Špačka, která se zformovala v průběhu roku 1917, byla s Maffií v kontaktu prostřednictvím ředitele Českomoravského úvěrního ústavu Josefa Pospíšila. ${ }^{43}$

$\mathrm{V}$ případě tzv. profesorské maffie se nám zatím přímou vazbu na Tajný výbor nalézt nepodařilo. Dochované memoáry jednoho z jejích členů, Ferdinanda Špíška, středoškolského učitele francouzštiny a v meziválečném období zaměstnance československého ministerstva školství a národní osvěty, nám však umožňují udělat si představu o způsobu, jakým byly uvedené profesní maffie formovány. Ke spolupráci Špíška v únoru 1918 vyzval profesor žižkovské reálky Antonín Beer, který mu oznámil, že byl z pověření osmičlenné profesorské maffie vybrán jako její devátý člen. Za cíl jejich činnosti Beer označil přípravné práce „pro reformu a organizaci československého školstvi osvobozeného národa po válce“. Dalšími členy sdružení byli středoškolští učitelé: matematik Bohumil Bydžovský, historik Florián Horut, hospodářský historik Josef Kazimour, zeměpisec Stanislav Nikolau, př́rodovědec Vojtěch Rosický, matematik a fyzik Miloslav Valouch a historik umění František Žákavec. Jejich schůzky se konaly ve spolkových místnostech Jednoty českých matematiků a fyziků v pražské Křemencové ulici. Jednotlivým členům sdružení byly přiděleny referáty o podrobnějších otázkách celé akce. Důraz byl kladen na přípravu radikálních

39 Cit. dle: Křestan, Jiří: Závistivý zeměplaz? Zdeněk Nejedlý, Sukova aféra a případ Talichův. In: Hrdinství a zbabělost v české politické kultuře 19. a 20. století. Výběr příspěvků ze stejnojmenné konference, která proběhla ve dnech 25.-27. října 2006. Eds. J. Randák - P. Koura. Praha 2008, s. 317.

40 Tamtéż, s. 319.

41 Těšínská, Emilie - Schwippel, Jindřich: Masarykova akademie práce. In: Bohemia docta. K historickým kořenům vědy v českých zemích. Eds. A. Míšková - M. Franc - A. Kostlán. Praha 2010, s. 288.

42 MÚA, Ferdinand Špíšek, kart. 2, Moje paměti a úvahy, 2. díl, Profesorská Maffie.

43 Špaček, Stanislav: $K$ dějinám založeni Masarykovy akademie práce. Jubilejní vzpomínka. Zvláštní otisk ze Sborníku MAP, IX, 1935. 
změn v personálních otázkách na středních školách a na zemských školních radách. Předmětem úvah byli rovněž úředníci působící ve Vídni a jejich využitelnost v plánovaném československém ministerstvu školství. ${ }^{44}$

\section{Možnosti a limity maffistické legendy}

Při sledování činnosti české domácí protirakouské rezistence z let 1914-1918 jsme odkázáni především na vydané i nepublikované materiály memoárového charakteru, vzniklé až následně v období První československé republiky. Tato skutečnost bývá již tradičně vysvětlována především už samotnou utajenou až konspirační podstatou činností maffistů, kteří se často ani navzájem neznali. ${ }^{45}$ Netřeba přitom zdůrazňovat, že paměti jako historický pramen představují zdroj značně nejistý podléhající celé řadě vlivư a dávající tak prostor nejrůznějším zkreslením a výkladům. V roce 1920 popsala tento problém již zmíněná Milada Paulová: „[...] lidé nevolky fantazíruji, matou ideologii, [...] je třeba prijít zas a znovu $k$ téže osobě a dotazovat se. Téměr každý nový rozhovor boři opět to staré a je třeba revize. "46 Ačkoli se její slova vztahovala konkrétně na jihoslovanské prostředí, není jistě důvod dělat si iluze, že by tomu v meziválečném Československu bylo jinak. Jedním z cílů memoárové literatury byla nepochybně snaha legitimizovat uspořádání mladé Československé republiky a obsazení vedoucích míst v novém státě, včetně výjimečného postavení T. G. Masaryka, Edvarda Beneše a jejich spolupracovníků ze zahraničního i domácího odboje. ${ }^{47}$

Osob, hlásících se mezi aktivní účastníky domácího odboje s postupem času přibývalo. Hranice, umožňující odlišit skutečné odbojové činy motivované touhou po samostatném státu, však přitom byly často jen obtížně rozpoznatelné od nejrůznějších projevů občanské neposlušnosti, jako byly urážky vznášené na adresu císaře. ${ }^{48}$ Tyto tendence se projevovaly i ve vztahu k Maffii. Její představitelé si je plně uvědomovali. V záŕí 1922 proto Šámal na popud Bohuslava Franty vyzval Aloise Rašína, Antonína Hajna, Jaroslava Kvapila, Bedřicha Štěpánka a Josefa Scheinera, aby se sešli s cílem zaznamenat zásadní okamžiky z dějin Maffie. Franta na zdo̊vodnění tohoto kroku uvedl: „[...] jednak věc upadá v zapomenutí a mimo to, čas od času, vystupuji lidé, známi ve válce svým rakušáctvím, kteři nyni tvrdi, že byli činni v revolučnim smyslu a že byli činni dokonce ve styku s Maffii. " Obdobně smýšlel

44 MÚA, Ferdinand Špíšek, kart. 2, Moje paměti a úvahy, 2. díl, Profesorská Maffie.

45 Přemysl Šámal k tomu uvedl: „Pokud se týče Maffie, byla tato uzavřenou společností, organizovanou tak, že vždy jen zcela nepatrný počet účastniků se navzájem znal, tak aby prozrazeni celé organizace bylo nemožno. $Z$ nich však každý vědèl, že jest členem organizace, a obstarával na své nebezpeči určité riziko činnosti, která mu byla svěřena. “AKPR, KPRT, sg. T 125/22, kart. 81, P. Šámal F. Štěpánkovi (továrník v Hostivaři), 16. listopadu 1925.

46 M. Paulová J. Bidlovi, 28. srpna 1920, Střet generacı? Paměti a vzájemná korespondence zakladatelů české byzantologie a slovanských studií, s. 210, č. 32.

47 Kubů, E. - Šouša, J.: T. G. Masaryk a jeho c. k. protivníci, s. 10.

48 Srov. Souhrnná hlášeni presidia pražského mistodržitelstvi o protistátni, protirakouské protiválečné činnosti v Čechách 1915-1918. Ed. L. Otáhalová. Praha 1957.

49 AKPR, Přemysl Šámal, sg. 236/1922, kart. 14, P. Šámal bývalým členům Maffie, 26. září 1922. 
i Přemysl Šámal: „Mnoho se však zapominá, a také jsme lidé smrtelní. Odešel Kalina, zemřel Rašín a někteři z nás již dospívaji hranice věku, která neni zárukou dlouhého života. [...] Rádi bychom měli již jednou seznam členů Maffie pevně ohraničený, poněvadž začínaji se nám hlásiti členové, o kterých žádný z nás neměl potuchy a kterých jsme při práci nikdy nevidèli. "Kanclér se rovněž pokusil o definici maffisty: „Myslim, že z našich spolupracovniků za členy Maffie lze považovati toho, kdo z přikazu našeho konal určité úseky revoluční práce, se kterouž spojeno bylo nebezpeči persekuce. "Své vzpomínky však maffisté prozatím nepokládali za vhodné zveřejnit, když Šámal uvažoval o jejich uložení v Národním muzeu nebo některé podobné pamětové instituci. ${ }^{50} \mathrm{~S}$ tímto stanoviskem korespondovalo i vyjádření Bohumila Mareše, který společně se svými rodinnými příslušníky strávil v roce 1915 v souvislosti s tzv. knoflíkovou aférou řadu týdnů ve vězení. V září 1923 v dopise, adresovaném Jaroslavu Werstadtovi, uvedl: „Zdá se mi dnes při tak rozháraných poměrech doba nevhodná sdělovati veřejnosti jakékoliv dojmy a zkušenosti z dob tak zvané Maffie, nebot’ jsou dnes dle mého náhledu osoby, jež hrály v dobách těch zbabělou roli, dnes pro utišeni dně̌nich poměrů na svém mistě, aby tak také mohly napravit, co zavinily, at’ vědomě, neb nevědomě v dobách tak krušných. "Dopis končil smírlivými slovy: „Netrpěl jsem jen já, trpělo tisíce jiných, což na tom, máme Republiku, ted' klid, dělali jsme, co jsme mohli, a ti po nás at’ dělaji co uměji. ""51

Oficiálni výkladovou linii protirakouského odboje reprezentovaly zejména Masarykův spis Světová revoluce a Benešova Světová válka a naše revoluce, které poprvé vyšly v roce 1925, resp. 1927 a 1928. ${ }^{52}$ Jejich vydavatelem byla nakladatelství Orbis a Čin. Zmíněnou oficiálnost zdůrazňovalo i vlastní provedení obou titulů, když po odstranění přebalu s portrétem Masaryka či Beneše nalezl čtenář desky se zlatě provedeným rukopisným názvem knihy a podpisem autora, kterým jakoby stvrzoval pravdivost jejího obsahu. Naší pozornosti by neměly uniknout ani oba nakladatelské domy. Čin - tiskové a nakladatelské družstvo československých legionářů bylo založeno 7. listopadu 1920. Jeho činnost se soustředila na vydávání užitkových legionářských publikací a literatury s národní a demokratickou revoluční tématikou. Jeho kmenovým autorem byl prezident Masaryk. Vycházely zde jak jeho sebrané spisy, tak díla věnovaná Masarykově osobě. ${ }^{53} \mathrm{O}$ něco mladší Tiskařská, nakladatelská a novinářská společnost akciová Orbis byla založena 27. března 1921. Podnět k jejímu vzniku dalo ministerstvo zahraničních věcí, přičemž vliv Edvarda Beneše zajištoval vedoucí tiskového odboru ministerstva zahraničních věcí Jan Hájek. Úkolem nakladatelství bylo vydávání české i cizojazyčné státně-propagační literatury. Hlavní úkoly Orbisu směřovaly zejména do zahraničí. ${ }^{54}$ Po stránce politické mělo nakladatelství sledovat „směrnici prezidentovu, majici na žreteli prospěch celého státu“. 55

50 AKPR, Přemysl Šámal, sg. 142/1936, kart. 38, P. Šámal B. Štěpánkovi, 18. února 1924.

51 A AV ČR, Jaroslav Werstadt, inv. č. 478, kart. 11, B. Mareš J. Werstadtovi, 26. září 1923.

52 Masaryk, T. G.: Světová revoluce; Beneš, E.: Světová válka a naše revoluce. Srov. pozn. 5.

53 Lexikon české literatury. Osobnosti, díla, instituce, 1. díl A-G. Ed. V. Forst a kol. Praha 1985, s. 500-502.

54 Tamtéż, 3. díl M-̌̌. Praha 2000, s. 686-692. Dejmek, Jindřich: Pražské ministerstvo zahraničí a sebeprezentace Československa mezi světovými válkami. In: Věře Olivové ad honorem. Sborník příspěvkủ k novodobým československým dějinám. Eds. E. Broklová - M. L. Neudorflová. Praha 2006, s. 94-97.

55 Národní archiv, Praha, Orbis, Praha, kart. 1, První kniha protokolů správní rady 1920-1928, Zápis z první schůze výboru pro zřízení akciové nakladatelské společnosti, 4. prosince 1920. 
Je samozřejmé, že hlavními vykladači zmíněné směrnice byli T. G. Masaryk a Edvard Beneš.

Vznik Maffie byl dáván do přímé souvislosti s vlastní činností obou vůdců československé zahraniční akce. Masaryk kladl počátky vzniku Maffie ještě do doby před svým odchodem do exilu v prosinci 1914, když jako její počátek označil schůzku, kterou svolal k advokátovi Václavu Boučkovi. Dalšími účastníky tohoto setkání měli být: benešovský advokát a předseda družstva Pokrok, které vydávalo deník Čas, František Veselý, pražský stavitel Josef Záruba-Pfeffermann, redaktoři Času Cyril Dušek a Jan Herben, nakladatel Gustav Dubský, pražský advokát Přemysl Šámal a profesor pražské obchodní akademie Edvard Beneš ${ }^{56}$ Poslední jmenovaný, který se 30. září 1919, hned ve svém prvním vystoupení v Národním shromáždění, přihlásil ke spolupráci s Maffií, když sám sebe označil za sekretáře Maffie, ${ }^{57}$ ve svých memoárech tuto schůzku potvrzuje. Vlastní ustavení Maffie však dává až do souvislosti s Masarykovou emigrací, když měl na žádost odjíždějícího profesora za úkol vytvořit z „politických lidi“ tajný komitét, který by byl doma rozvětven, disponoval tajným spojením s cizinou, aby zajistil informovanost emigrace o vývoji na domácí scéně, a byl ve stálém kontaktu s oficiální českou a vídeňskou politikou, přičemž by dokázal vedení domácí politiky zákulisně ovlivňovat. Podle Masarykových představ měla mít takto vytvořená organizace k dispozici svou tajnou tiskárnu a dostatek oddaných lidí, kteří by při případném zatčení byli schopni a ochotni ihned nahradit své kolegy. Masaryk rovněž doporučoval rozšíření těchto aktivit na venkov. ${ }^{58}$

První schůzku Maffie ve složení Edvard Beneš, Alois Rašín, Přemysl Šámal, Karel Kramář a Josef Scheiner datoval Beneš do března 1915, když v souladu s Masarykem pasoval sám sebe do hlavní role v tomto sdružení. Již dříve zmíněným zatčením Kramáře, Scheinera a Rašína v létě 1915 a jeho zářijovým odchodem do exilu se podle Beneše uzavřela „proni perioda činnosti Maffie, pro naši akci zahranični snad nejdůležitějši “. ${ }^{59}$ Zároveň však uznával, že i pro další práci zahraniční akce zůstával nezbytný kontakt s domácím odbojem. ${ }^{60}$ Postavení Maffie pak hodnotil jako „význačné, ale přesně vymezené“, když její poslání shrnul do tří hlavních oblastí: 1) zajištění kontaktu zahraničního odboje s domácí politickou scénou, který legitimizoval jeho postavení v očích dohodových mocností; 2) možnost ovlivňovat politický vývoj v Čechách; 3) zpravodajská činnost, týkající se zejména vojenských, hospodářských a finančních poměrů uvnitř rakousko-uherské monarchie. ${ }^{61}$

Historik Jaroslav Werstadt v souvislosti s rokem 1914 hovořil o třech centrech českých protirakouských aktivit. První z nich - „realisticke““ - reprezentované T. G. Masarykem, spojoval se stranou státoprávně-pokrokovou, „mladočeské, za jehož hlavní postavu označil Karla Kramáře, se stranou národně-svobodomyslnou, a „radikálni“, z jehož řad vzešel první československý politický emigrant Lev Sychrava, se stranou státoprávně-pokroko-

56 Masaryk, T. G.: Světová revoluce, s. 32.

57 Národní shromáždění československé 1918-1920, 77. schůze, část 2/7 (30. 9. 1919). https://www.psp.cz/ eknih/1918ns/ps/stenprot/077schuz/s077002.htm, citováno 23. 2. 2017.

Beněs, E.: Světová válka a naše revoluce I, s. 36.

59 Tamtéż, s. 73.

60 Tamtéž, s. 84.

61 Tamtéž, s. 89-90. 
vou. Tato tři revoluční střediska se podle Werstadta v průběhu roku 1915 „spojila $k$ akci společné a jednotné “a položila tak základ ke vzniku Maffie. Jmenovaný historik však zároveň připouštěl, že mladočeské aktivity, přestože probíhaly v souladu a ve spolupráci s činností tajného revolučního výboru, si stále uchovávaly jistý odstup a určitou míru nezávislosti. ${ }^{62}$

Zajímavou charakteristiku činnosti Maffie předložil na jaře 1923 československý vyslanec v Bělehradě Jan Šeba jugoslávskému králi Alexandrovi I. Podle ní byla Maffie tajným spolkem, který v Čechách před svým odchodem do zahraničí založil T. G. Masaryk. Jako prvního tajemníka Šeba jmenoval Edvarda Beneše. Podle vyslance tento spolek řídil celé protihabsburské hnutí v Čechách a stál v čele politiky českého parlamentního svazu. Maffii Šeba přiznával i hlavní podíl na manifestu českých spisovatelů a deklaraci svazu českých poslanců z května 1917, tříkrálové deklaraci z 6. ledna 1918, slavnostní přísaze českého národa z 13. dubna 1918 a na uspořádání pražského kongresu potlačených národů 18. května 1918. Neopomenul zmínit ani vliv Maffie na jihoslovanský klub ve vídeňské ř́ršské radě. Maffisté byli dále představeni jako organizátoři pasivní rezistence českého národa vůči válečným aktivitám rakousko-uherské monarchie, především ve věci válečných půjček, dodávek potravin a produkce uhlí, a jako realizátoři politické a válečné špionáže. Coby „hlavni členy Maffie“ Šeba uvedl Přemysla Šámala, Bedřicha Štěpánka, Karla Kramáře, Josefa Scheinera, Aloise Rašína, Antonína Hajna, Františka Soukupa, Bohuslava Frantu, Antonína Kalinu, Josefa Svatopluka Machara, Jaroslava Kvapila, Cyrila Duška, Františka Síse, Jana Hajšmana, Aloise Jiráska, Antonína Švehlu, Václava Klofáče a Františka Staňka. ${ }^{63}$ Čtyři posledně jmenovaní muži působí v tomto výčtu přinejmenším nevěrohodně. Uvedení Aloise Jiráska lze bez potíží zdůvodnit jeho podílem na projevu českých spisovatelů v květnu 1917 či vystoupením z 13. dubna 1918 ve Smetanově síni, kde za hojné účasti Jihoslovanů přednesl text tzv. národní př́isahy. ${ }^{64}$ U tří zbývajících však Šebu k zařazení do jeho výčtu vedlo spíše jejich aktuální postavení na československé politické scéně. Ministerského předsedu Antonína Švehlu bychom v seznamech maffistů nalezli poprvé a naposledy mezi osobami pozvanými na 28. října 1919 k audienci na Pražský hrad. ${ }^{65}$ Předseda Československé strany národně sociální, první československý ministr národní obrany a dlouholetý senátor Václav Klofáč se pak mezi maffisty ocitl pouze v březnu 1920, když nescházel na Drtikolově tablu Maffie. ${ }^{66}$ $\mathrm{V}$ př́ípadě předního funkcionáře agrární strany a jejího dlouholetého poslance Františka Staňka bychom však jeho jméno v seznamech členů Maffie hledali marně. ${ }^{67}$

Utváření široce pojaté maffistické legendy dávalo dostatek prostoru pro využití této instituce ze strany československé státotvorné propagandy. Maffie, prezentovaná jako

62 Werstadt, J: Politické plány české Maffie v proním roce války, s. 413-414.

63 Arhiv Jugoslavije, Beograd, 74 Dvor Kraljevine Jugoslavije, fasc. 6, kart. 2, Zpráva o Maffii určená jugoslávskému králi Alexandru I. Podle kontextu byl jejím autorem československý vyslanec v Bělehradě Jan Šeba, který ji připravil při svém nástupu do úřadu v roce 1923.

64 Paulová, M.: Tajný výbor [Maffie] a spolupráce s Jihoslovany v letech 1916-1918, s. 424-435.

65 AKPR, KPR, inv. č. 559, sg. D 4382, kart. 46, Seznam členů Maffie pozvaných na audienci 28. ř́jna 1919.

66 Český svět, roč. XVI, č. 29, 25. března 1920, s. 39.

67 Österreichisches Biographisches Lexikon 1815-1950 však Františku Staňkovi maffistickou minulost přiznává. Srov. http://www.biographien.ac.at/oebl?frames=yes, citováno 7. 3. 2017. 
nadstranický orgán, mohla překrýt některé vzájemné rozpory, panující mezi jednotlivými skupinami, tvořícími domácí odboj, a zároveň těsněji provázat jejich jednání s aktivitami Masarykovy a Benešovy zahraniční akce. Propojení s Hradem umocňoval i fakt, že se středisko Maffie společně s osobou Přemysla Šámala přestěhovalo do Kanceláře prezidenta republiky na Pražský hrad. ${ }^{68}$ Zdá se, že ve sjednocující potenciál Maffie věřil i prezident Masaryk, který ještě na konci roku 1921 hovořil se Šámalem o možnosti obnovit ji „ve formě jakési neoficiálni státni rady“, přičemž měl konkrétní představu i o jejím personálním obsazení. Vedle maffistů z doby první světové války Edvarda Beneše, Aloise Rašína, Josefa Scheinera, Přemysla Šámala a Jaroslava Preisse, se v jejím rámci měli scházet předseda agrárníků Antonín Švehla, jeho Jan Malypetr, sociální demokraté Rudolf Bechyně, Vlastimil Tusar a Antonín Hampl, předseda řady úřednických vlád Jan Černý, národohospodář Karel Engliš, vůdce moravského křídla národnědemokratické strany Jaroslav Stránský, bývalý ministr s plnou mocí pro správu Slovenska a od roku 1921 ministr školství Vavro Šrobár, generální inspektor československé armády Josef Svatopluk Machar a generál Otakar Husák. Pro odborné otázky Masaryk zamýšlel zvát podle potřeby k jednání diplomata Vojtěcha Mastného, historika a diplomata Kamila Kroftu, zástupce ministra zahraničních věcí Václava Girsu, národního socialistu Jiřího Stříbrného, předsedu téže strany Václava Klofáče, senátora za československou stranu lidovou Methoda Jana Zavorala, jejího předsedu Jana Šrámka a orientalistu Aloise Musila. ${ }^{69}$

Skutečnost, že domácí odboj netvořil jednolitý celek, nám potvrzují prohlášení některých jeho účastníků i dalších současníků, stojících mimo odbojové dění. Uvést například můžeme Josefa Zárubu-Pfeffermanna, jenž v roce 1937 uvedl: „Je správný názor, že to, čemu se dnes ř́ká ,Maffié, je něco, co evolučně vznikalo z mnohých separovaných a často nepřátelských zárodků. "70 Národohospodář Cyril Horáček, který v červenci 1919 převzal od Aloise Rašína ministerstvo financí, ve svých pamětech činnost Maffie do jisté míry zpochybňoval a dával najevo přesvědčení o dodatečném zveličování jejích zásluh: „Nepodceňuji dojista horlivou činnost mužư, kteři doma převrat chystali, ale utvořily se mnohé legendy a ještě se mnohé vybásnilo. Velmi se oslavuje činnost tzv. ,Maffie؛. Zajisté hned od počátku války se u nás tvořily soukromé kroužky, které horlivě politizovaly a sbíraly tajné zprávy o válečném průběhu, pravdivé i nepravdivé. Jednim takovým kroužkem byla i tato ,Maffie‘, ale bylo takových ,maffii více. [...] Mám dojem, že se ex post konstruovalo něco, co v zárodku zde bylo, ale co nemèlo ten význam, který se mu později přikládal. ,Maffie' skutečně konala jisté služby, když zprostředkovala styk mezi zahraničnimi vyslanci našimi a domácími politiky. Také po propuštěni Kramáře a Rašina konala snad již př́pravy pro očekávaný převrat. Ale celkem, Maffie‘ nevystoupila nikdy ze svého

68 S tímto přesunem se pojí následující epizoda: Když se Alois Junger, majitel pražského hotelu Zlatá husa, v srpnu 1919 obrátil na Jana Hajšmana s žádostí o proplacení pobytu za pány Elisea Ricarda Gomeze (zástupce uruguayského generálního konzula), chorvatského politika Ante Tresiće-Pavičiće a spolupracovníka Maffie Emila Šimka, kteří zde pobývali na přelomu července a srpna 1918, předal Hajšman tuto žádost Šámalovi. Ten účtovaný obnos „jménem Maffie“ uhradil, o čemž Jungera informoval dopisem psaným na papíru s hlavičkou Kanclér prezidenta republiky. AKPR, Přemysl Šámal, sg. 546/21, kart. 13, P. Š́mal A. Jungerovi, 22. ledna 1920.

69 AKPR, KPRT, sg. T 125/22, kart. 81, Interní záznam P. Šámala, 4. listopadu 1921.

70 ANM, MAFFIE, inv. č. 43, kart. 3, Josef Záruba-Pfeffermann M. Paulové, 30. června 1937. 
romantického př́tmi a jeji působnost v prvých dobách nemohla býti ani účinná, ani patrná, jinak by dojista neušla Argusovým zrakưm policie a vojenských špehounů, kterých bylo všude plno. "71

Ještě jednoznačněji, a to i ve vztahu k československé zahraniční rezistenci, vyznívají vzpomínky mladočeského předáka Františka Síse, spojovaného od samého počátku právě s Maffií. Konstatoval, že jeho spolustraníci pokládali za hlavní reprezentanty válečné politiky své vlastní stranické orgány a Maffii vnímali od počátku války za prostředníka mezi vnitřní a zahraniční revolucí. Sís tak zároveň dal najevo, že jako Maffii chápal pouze úzce vymezenou skupinu osob, pro níž jsme již dříve použili označení Tajný výbor. Oficiálně budovaný obraz Maffie pak Sís narušoval zejména ve vztahu k Edvardu Benešovi, když uváděl: „Benešovy výroky v jeho knize, že před svým odjezdem organizoval Maffi atd., jsou nesmyslem velmi jednostranným. Nebyl ani pruni, který přišel s myšlenkou akce, nebot' Maffie v národni straně svobodomyslné začala fungovat hned po vypuknutí války a měla prvni zahranični spojeni. A co dr. Beněs organizoval? Ani ne podzemni činnost vyzvědačskou, to byly jen jednotlivé malé úseky, ale neměl ani vojenský, ani válečný průmysl, ani ostatni průmysl, ani železnice a dopravnictví, ani finančnictví, ani aprovizaci - prostě ničeho skutečně neobsáhnul, aby se mohlo mluvit o organizaci. Stejně neučinil nic politicky, neměl k politice téměr př́stupu, měl př́stup jedině $k$ sociálni demokracii, ale ta nebrala na něho nejmenšího zřetele, ani ve výkonném výboru, ani v Právu lidu. O vnitřni organizaci provádèné ve skupině národni strany svobodomyslné, která byla proní vážnou a soustavnou organizací válečnou, ani Beneš ničeho nevěděl. "72 Tato jednoznačná slova z roku 1929 byla určena pro potřeby historičky Milady Paulové. Ve svých Kapitolkách z činnosti maffie, publikovaných pravidelně od září téhož roku v Národnich listech, však Sís volil slova výrazně opatrněji. ${ }^{73}$

\section{Maffie a tzv. spor o zásluhy}

Od samého vzniku samostatného státu byla československá společnost konfrontována se stížnostmi, vznášenými ze strany některých občanů či celých skupin, pramenícími z pocitu nedostatečného ocenění jejich, at již skutečných, či domnělých, zásluh o vznik samostatného státu. ${ }^{74}$ Počátek dvacátých let byl rovněž poznamenán rozepří mezi Masarykem a Benešem na jedné a Karlem Kramářem na druhé straně. ${ }^{75}$ Je samozřejmé, že se tyto dohady nemohly vyhnout ani Maffii, přestože byla od prvních dnů existence Československé republiky prezentována jako nejbližší spojenec a spolupracovník zahraniční

71 A AV ČR, Cyril Horáček, inv. č. 1, sg. I c, kart. 1, Vzpomínky, f. 142.

72 A AV ČR, Milada Paulová, inv. č. 815, sg. III g, kart. 34, Př́́pravný materiál pro Dějiny Maffie.

73 Sís, František: Kapitolky z činnosti maffie, Národní listy (na pokračování) od 27. záŕí 1929.

74 Maffista Josef Svatopluk Machar tyto představy vyjádřil slovy: „Co jste čekali od našeho československého státu? Přiznejte si: pronikavý prevrat ve suém životě. Materiálni výhody. Mista, prebendy, lehké živobytí... Málokdo chtěl zưstat na mistě, kde stál a kde svou životni brázdu táhl. Príšel převrat a vy jste chtèli hodit pluhem a prèrátit se také. Kdo byl na venku, chtěl do Prahy, kdo byl v Praze, chtěl do ministerstva - tisíce a tisíce pocítily v sobě, že jsou povolani a chtěli být vyvolenými. Třista let čekali jsme na svou volnost - když přš̌la, měla znamenat pro generaci, která se jí dožila, úr̆ad, prebendu, titul, změnu povoláni [...]." Machar, Josef Svatopluk: Časové kapitoly. Praha 1920, s. 8-9.

75 Kovtun, Jiří: Republika v nebezpečném světě. Éra prezidenta Masaryka 1918-1935. Praha 2005, s. 388-401. 
akce a Masaryk ani Beneš si zásluhy za její činnost nikterak nepřivlastňovali. Oba přitom zdůrazňovali, že maffistické aktivity byly důležitou součástí „československé revoluce “.76 Tento tzv. spor o zásluhy na vzniku republiky se vyostřil v roce 1924 a přenesl se i do dalších let. Polemika, do níž se postupem času zapojila celá řada osob, a která postupně získávala nové konotace, se měnila v souboj Hradu s domácími politickými představiteli. ${ }^{77} \mathrm{Z}$ aktérů těchto diskuzí můžeme uvést alespoň na straně Hradu stojícího Ferdinanda Peroutku jako autora spisku s př́značným názvem Kdo nás osvobodil? ${ }^{78}$ na straně druhé pak Viktora Dyka. $^{79}$

Sporem o zásluhy byla nepochybně poznamenána i snaha hlavního představitele Maffie Přemysla Šámala, aby prezident Masaryk udělil výslovně „členům Maffie“ jako výraz uznání jejich podílu na vzniku republiky vlastnoručně podepsaný diplom. K realizaci tohoto plánu, vážícího se k roku 1919, však nakonec nedošlo a účastníci domácího odboje se dočkali ocenění až v roce 1925 formou československé revoluční medaile. Ta však, narozdíl od původně zamýšleného diplomu určeného výslovně členům Maffie, byla udělena osobám, které „přispěly vynikajicím zpuisobem k revolučnímu hnutí domácímu“. Využitím československé revoluční medaile bylo navíc udělení vyznamenání za zásluhy o domácí odboj předáno do kompetence ministra národní obrany. Prezident Masaryk, jenž měl podle původního plánu ocenění osobně předávat, se tak vyhnul př́ípadným nařčením, že se ocenění dostalo pouze jeho lidem. ${ }^{80}$ Jak bude následně ukázáno, spor o zásluhy zřejmě také přiměl Edvarda Beneše a jeho spolupracovníky k úpravám některých dokumentů týkajících se vzájemné komunikace mezi zahraničním odbojem a Maffií, zveřejněných ve třetím svazku Světové války a naši revoluce.

V době první světové války spočíval hlavní úkol Maffie vưči československé exilové reprezentaci ve Francii především v samotné možnosti vzájemné komunikace. Spojení s domácím odbojem tak mělo v očích dohodových politiků i tamějšího veřejného mínění legitimizovat aktivity Masarykovy skupiny jako znalce a reprezentanta českých národních zájmů. Fakt, že pražský Tajný výbor přijímal pokyny z Paříže, napomáhal vytváření dojmu, že česká politika představuje jednotný a Dohodě podřízený celek. Zprávy špionážního charakteru o situaci v politické, hospodářské a sociální oblasti i o otázkách vojensko-politických a vojensko-technických, zasílané Maffií do Paříže, však měly spíše okrajový význam. Tento v zásadě jednosměrný pohyb instrukcí mezi Prahou a Paříží Maffie plně respektovala.

76 Beneš, E.: Světová válka a naše revoluce I, s. 84-85.

77 Srov. Klimek, Antonín: Boj o Hrad. 1. Hrad a Pětka. Vnitropolitický vývoj Československa 1918-1926 na půdorysu zápasu o prezidentské nástupnictví. Praha 1996, s. 326-334; Masaryk, T. G.: Světová revoluce, s. 313-317. Galandauer, Jan: Muži 28. řínna a „spor o zásluhy“ na vzniku Československa. Muži října 1918. Osudy aktérů vzniku republiky československé. Střed/Centre. Časopis pro mezioborová studia Střední Evropy 19. a 20. století. Supplementum 1. Praha 2011. Ed. R. Kučera, s. 193-202; Vykoupil, Libor: Jiř Stříbrný. Portrét politika. Brno 2003, s. 111-121; Vašek, Richard: Prezident Masaryk jako anonymni publicista (1918-1935). Nepublikovaná disetační práce. FF UK. Praha 2012, s. 61-64.

78 Peroutka, Ferdinand: Kdo nás osvobodil? Praha 1927.

79 Tomeš, Josef: Viktor Dyk a T. G. Masaryk. Dvojí reflexe češství. Praha 2009, s. 72-74.

80 Hálek, J.: Diplom pro Maffii, s. 49-64. 
Jaro roku 1918 se na západní frontě neslo ve znamení německých ofenziv a situace se pro vojska Dohody postupně stávala do značné míry kritickou. Pocit, že se válečné štěstí přiklání na stranu Centrálních mocností, když Němci od března do srpna 1918 ostřelovali i Paříž a francouzská vláda uvažovala o přenesení svého sídla do Bordeaux, musel nutně ovlivnit také pozici československé exilové reprezentace i její komunikaci s Prahou. Dohodové mocnosti se ve stejnou dobu definitivně rozloučily s myšlenkou na uchování rakousko-uherské monarchie. Tato situace se zřetelně projevila v depeších, odesílaných v době mezi květnem a červencem 1918 Edvardem Benešem do Prahy.

Přestože předpovídal ještě dlouhou válku, ujištoval Beneš pražskou Maffii, že „naše politická situace je výborná “. ${ }^{11}$ Spojenci však byli dle jeho slov vyčerpáni a Beneš nevylučoval ani možnost německé okupace Paříže. Naději na úspěch v jeho očích skýtaly pouze Spojené státy americké. Dohoda sice uznávala do budoucna nezávislost Československa, za svůj postoj však žádala spolupráci směřující k jakémukoli oslabení Centrálních mocností. ${ }^{82}$ Již ve zprávě z 10 . května Beneš volal po přípravě „přímé akce“ v českých zemích, aby v Paříži „viděli, že všemi prostředky pracujeme“. ${ }^{83}$ Na konci května pokračoval: „Nežádáme, abyste provedli nyni všeobecnou revoluci. Je třeba s revoltou čekat na vhodný okamžik. Ale je nezbytno dokázat Spojencům, že jste s nimi. "84 „Žádáme o toto: Soustavnou sabotáž politickou, hospodářrkou a vojenskou. Začněte pasivni resistenci administrativni, města, okresy, obce, úřednici, dopravnictvi - v̌secko pokud možno začněte zarážet. Je třeba vyvolat naprostou vnitřni anarchii. Provádět pokud možno stávky, organizovat dále ničeni lokomotiv, dopravnictví a pokusit se o vyhazováni munice, továren. Udělejte, co je ve Vaši moci. Ale začněte na široké základně a systematicky. "85 Obdobný požadavek obsahovala i zpráva ze 14 . června. ${ }^{86}$ Jako důkaz souznění českého a domácího zahraničního odboje Beneš mimo jiné požadoval: „Stávky a sociálni bouře, soustavné ničeni munice, komunikací, továren atd., zejména začít ničeni pomocí požárů, počít teror, a to zuláště a zejména ve Vidni jako hlavním ohnisku. "87 V podobném tónu se nesly i červencové instrukce. ${ }^{88}$

Zmíněné pokyny však byly do Prahy s největší pravděpodobností doručeny až 6. září 1918. ${ }^{89}$ Vlastní kroky realizované v daném období Maffií pak byly výrazně odlišné a její aktivity rozhodně nesměřovaly k vyvolání anarchie a teroru v zázemí, po němž Edvard

81 Zpráva E. Beneše do Prahy, 10. května 1918, in: Beneš, E.: Světová válka a naše revoluce III, s. 154-155, č. 48 .

82 Zpráva E. Beneše do Prahy, 14. června 1918, Tamtéž, s. 164-167, č. 52.

83 Zpráva E. Beneše do Prahy, 10. května 1918, Tamtéž, s. 154-155, č. 48.

84 Zpráva E. Beneše do Prahy, 27. května 1918, Tamtéž, s. 162-164, č. 51.

85 ANM, Přemysl Šámal, inv. č. 107, kart. 2, Zpráva E. Beneše do Prahy, 27. května 1918.

86 Zpráva E. Beneše do Prahy, 14. června 1918, in: Beneš, E.: Světová válka a naše revoluce III, s. 164-167, č. 52.

87 ANM, Přemysl Šámal, inv. č. 107, kart. 2, Zpráva E. Beneše do Prahy, 14. června 1918.

88 Zpráva E. Beneše do Prahy, 8. července 1918, in: Beneš, E.: Světová válka a naše revoluce III, s. 174-177, č. 56. Srov. Marès, A.: Edvard Beneš od slávy k propasti, s. 79-85.

89 Beneš, E.: Světová válka a naše revoluce III, s. 174-175, pozn. 1. Tuto verzi akceptovali i Zdeněk Kárník a Benešův životopisec Jindřich Dejmek. Srov. Kárník, Z.: Edvard Beneš a Maffie v nejtěžšim obdobi Velké války, s. 17. Dejmek, J.: Edvard Beneš. Politická biografie českého demokrata, s. 197. S tímto tvrzením korespondují i archivní prameny vážící se k osobě švýcarského Čecha Eduarda Bernarda, který měl zprávy doručit: Srov. AKPR, Přemysl Šámal, sg. 276/1921, kart. 11, Eduard Bernard. 
Beneš volal. Je ostatně velmi pravděpodobné, že by tomu tak bylo i v případě, že by zprávy z Paříže došly včas. Maffie se v roce 1918 připravovala na pokud možno klidné převzetí moci, když upřednostňovala uchování jistého stupně kontinuity při přechodu mezi monarchií a republikou. Agenda, kterou se její členové v této souvislosti zabývali, byla rozdělena na oblast správní, obchodní, finanční, právní atd. Již od jara pracovali maffisté na ocenění schopností a charakteru jednotlivých úředníků veřejné, politické, finanční a soudní správy, samosprávy, advokátů a notářo̊n, které by bylo možné využít v případě eventuálního převzetí politických úřadů. Tato práce byla svěřena Přemyslu Šámalovi a Aloisi Rašínovi, pro německé oblasti byli přibráni předseda Ústřední matice školské Jindřich Metelka, ředitel kanceláře téže organizace František Bělehrádek a ředitel Národní jednoty severočeské Josef Škába, pro Vídeň Ferdinand Pantůček, který zde působil jako rada Správního soudního dvora. U všech úředníků byla zjištována jejich „národně-politická spolehlivost“, autorita u obyvatelstva, organizační schopnosti a věcná způsobilost. Shromážděné informace byly dále zpracovávány. Šámal se věnoval plánům na obsazení politické služby, Rašín měl na starosti finanční úřady. ${ }^{90}$

Vedle personálního zajištění úřadů bylo, řečeno slovy Ferdinanda Pantůčka, rovněž třeba, aby nový stát, vzniklý na rozvalinách Rakouska, netrpěl nedostatky v žádném směru. „Bylo třeba zejména věnovati péči době prvé, době kdy nový stát bude podoben dítěti, jež počiná se teprve stavěti na nohy, samostatné chưzi ještě nezvyklé, a obzvláště bylo třeba se starati o to, aby nenastalo převratem v řádě právnim a v činnosti úředni nebezpečné interregnum, jež by zpưsobilo chaos a podporovalo nebo přivodilo vznik zhoubné anarchie a právni nejistoty. "Na začátku září 1918 vyhledali Pantůčka ve Vídni jeho maffističtí přátelé Bohuslav Franta a Přemysl Šámal. Uložili mu, aby vypracoval osnovy zákonů, které se zdály být nezbytnými pro fungování československého státu hned po převzetí moci, aby stát měl svou ústavu, právní řád a všechny své potřebné úřady. Pantůček žádosti vyhověl a 14. ř́ína přijel s hotovým textem k poradám do Prahy. Zároveň ředitel Živnostenské banky Jaroslav Preiss pracoval na osnově zákona o finančních a hospodářských aspektech vzniku nového státu. ${ }^{91}$

Přípravy bezpečnostní a vojenské stránky plánovaného převzetí moci byly svěřeny Josefu Scheinerovi a šéfredaktorovi Národních listů Františku Sísovi. Zatímco Scheiner připravoval členy Sokola, aby byli v momentě převratu připraveni okamžitě vystoupit jako národní vojsko, oslovil Sís začátkem srpna 1918 setníka Jaroslava Rošického, působícího tou dobou v pražské kadetce, a vyzval jej k př́ípravě plánu na zajištění kontroly nad

90 Rašín, Alois: Převrat z 28. října 1918, Národní listy, 28. října 1919 (Příloha k č. 256), s. 1. Text byl později publikován rovněž v revue Naše revoluce II, 1924, s. 332-342. Dokladem aktivit uvedených osob je s největší pravděpodobností seznam úředníků, uložený v rámci osobního fondu Přemysl Šámal v Archivu Národního muzea. Pro ilustraci můžeme uvést několik př́kladů zmíněných charakteristik: „Dvorni rada Alois Vlk - zemský školní inspektor - rozhodný Čech v každém směru, výtečný odbornik. [...] Referent říšsého soudu Jan Žáček - starý pán, zcela indolentní, jenž své misto pokládá za sinekuru - nereprezentuje české úřednictvo náležitěe [...] August rytír Popelka - prezident senátu správního soudního dvora - ryzího vlasteneckého smýšleni, znamenitý právnik, v̌sak již přes 60 roků stár, v práci málo expeditivni, pro činnost organizačni trochu těžkopádný, pro činnost výkonnou výborný. [...] Dvorni rada správního soudního dvora Ferdinand Pantůček - všeobecně znám, netřeba ho popisovati. [...] Okresni hejtman Bohumil Bradik - člověk morálně úplně deklasovaný. “ ANM, Přemysl Šámal, inv. č. 139, kart. 2, Osobní charakteristiky rakouských úředníků české národnosti.

91 Pantůček, Ferdinand: Příprava státního převratu ve směru zákonodárstvi a správy. Naše revoluce II, 1924, s. 351-354. 
vojenskou mocí a k jeho následné realizaci. Výsledkem byl program, na jehož základě měli být v českých a moravských posádkových městech vybíráni spolehliví důstojníci, jimž byly dány příslušné pokyny. Důstojníci pobývající na dovolené měli být instruováni, aby po návratu na frontu podporovali rozvrat v rakouské armádě. Pro Prahu „jakožto tepnu a středisko celého odboje " měly být zajištěny zbraně všeho druhu. Na moravském Slovácku a v jižních Čechách měly být zorganizovany tzv. zelené kádry, složené z vojenských zběhů. $\mathrm{V}$ pohraničních posádkách měly být vykonány přípravy k zajištění hranic nového státu. Na železnici měla být zorganizována sabotážní služba, která by v př́ípadě potřeby znemožnila poslání vojenských posil do Prahy k potlačení povstání. Na Šumavě měla být také zbudována tajná bezdrátová stanice, sloužící ke spojení s dohodovými státy. ${ }^{92}$

Průběh vyhlášení československé republiky a následující vývoj potvrdily opodstatněnost práce členů Maffie. Přes všechny nedostatky nebyly převratové dny poznamenány ani neúměrným chaosem, ani anarchií. Můžeme tak konstatovat, že se konkrétní kroky podniknuté Maffií ukázaly jako daleko prozíravější a vypracované s ohledem na důvěrnější znalost měnících se poměrů, než tomu bylo v př́ípadě Benešových výzev směřujících k vyvolání neklidu uvnitř habsburské monarchie.

Dokumenty ilustrující vzájemnou komunikaci mezi Paříží a Prahou byly v druhé polovině dvacátých let dvacátého století zveřejněny ve třetím svazku již zmíněných Benešových pamětí Světová válka a naše revoluce. Nejradikálněji znějící části těchto instrukcí však byly nahrazeny symbolickými třemi tečkami ${ }^{93}$ Editoři Jaroslav Werstadt, Jan Opočenský a Jaroslav Papoušek svůj zásah vysvětlili následovně: „Na několika málo mistech byl vypuštěn určitý pasus dokumentu z ohledů, jež jsou obvyklé a nutné při dokumentárních publikacích o věcech a lidech ještě živých. "94 Přestože všichni tři jmenovaní historici byli v uvedené publikaci uvedeni jako její editoři a Beneš ve své předmluvě konstatoval, že přijímají odpovědnost za uspořádání edice, ${ }^{95}$ pokládám představu, že by se ministr na vzniku knihy podílel pouze dodáním příslušných dokumentů, za velmi iluzorní. Jeho vliv byl zajištěn již samotným výběrem editorů. Hlavní slovo, soudě alespoň podle výše vyplacených autorských honorářo̊, patřilo Jaroslavu Werstadtovi, ${ }^{96}$ který se vždy hlásil ke svému úzkému vztahu s Edvardem Benešem. ${ }^{97}$

Historik Zdeněk Kárník, který v jedné ze svých studií na uvedené editorské zásahy upozornil již před více než dvaceti lety, konstatoval, že „celkem snad čturtročni orientace na chaos, teror a násilnou revoluci se jevila v poválečné činnosti E. Beneše tak křiklavým excesem, že musela pro tohoto velkého diplomata slavných shromážděni i kuloárů a posléze proního muže

92 Rošický, J.: Rakouský orel padá, s. 32-104.

93 Zprávy se však v plném znění dochovaly v opisech uložených v Archivu Národního muzea jako součást osobních fondů Antonín Hajn a Přemysl Šámal. Srov. ANM, Přemysl Šámal, inv. č. 107, kart. 2; ANM, Antonín Hajn, inv. č. 4243, kart. 152.

94 Beneš, E.: Světová válka a naše revoluce III, s. XVII.

95 Tamtéž, s. VII-VIII.

96 A AV ČR, Jaroslav Werstadt, inv. č. 875, kart. 16, Orbis, Tiskařská, nakladatelská a novinářská společnost akciová J. Werstadtovi, 27. června 1929.

97 Werstadt, J.: Ze vzpominek Starckových. Naše revoluce VII, 1931, s. 210-222. 
ve státě být nepř́jemnou vzpominkou, kterou nechtěl připomínat. "98 Přestože s Kárníkovými následujícími úvahami o extrémnosti situace, v níž Beneš uvedené instrukce psal, ${ }^{99}$ nelze než souhlasit, domnívám se, že rozhodující motivy, vedoucí k vypuštění sledovaných pasáží, se odvozovaly od právě probíhajícího sporu o zásluhy, který v době vydání Benešovy Světové války a naši revoluce rozhodně nebyl u konce. Fakt, že převzetí moci a vyhlášení Československé republiky proběhlo, narozdíl od Benešových instrukcí, nekrvavou cestou, mohl být ze strany odpůrců Hradu vnímán jako doklad odtrženosti pař́ižského vedení československé zahraniční akce od domácí reality. Je sice pravda, že Benešovy pokyny vznikaly v ovzduší obav z německé okupace Paříže, zatímco členové Maffie vycházeli ze zevrubné znalosti situace, ve které se dožívající Rakousko-Uhersko nacházelo, sotva však mohl ministr očekávat, že jeho političtí soupeři z druhé poloviny dvacátých let 20. století budou zmíněné události hodnotit takto objektivně. Beneš si tuto skutečnost ostatně plně uvědomoval, když v předmluvě ke třetímu svazku uvedl, že kniha je jeho odpovědí na výše uvedené polemiky. Zároveň zdůraznil, že z dokumentů, vztahujících se ke spolupráci zahraničního odboje s Maffí, je patrna úzká spolupráce a jednota obou skupin. ${ }^{100}$

\section{Závěr}

Je nepochybné, že zdůrazňování spolupráce mezi zahraniční protirakouskou rezistencí a domácím odbojem reprezentovaným Maffií představovalo pro vedoucí elity mladé Československé republiky v prvních poválečných letech důležitý argument při zdůvodňování a obhajobě uspořádání nového státu. Mimo jiné jim umožňoval opírat se o jednotný, ve veřejném prostoru už záhy jednoznačně dominující vzorec výkladu minulosti a s jeho pomocí dále utvářet kolektivní pamět a identitu svých spoluobčanů, formovat nové státní tradice a odvozovat i vlastní politicko-historickou legitimitu. ${ }^{101}$ Přestože původní étos, spojovaný se spoluprací zahraničního odboje a maffistů, postupně vyprchával, neupadla Maffie po celé meziválečné období v zapomnění. Ještě v polovině třicátých let došlo v několika případech k dodatečnému udělení československé revoluční medaile jako ocenění za maffistickou činnost.

98 Kárník, Z.: Edvard Beneš a Maffie v nejtěžším obdobi Velké války, s. 18.

99 Tamtéž, s. 17-21.

100 Beneš, E.: Světová válka a naše revoluce III, s. IX-X.

101 K problematice historické politiky a utváření kolektivní paměti srov. Havelka, Miloš: Poznání - pamět’ identita a několik obecnějšich úvah. Dějiny - teorie - kritika 4, 2007, s. 256-268. Stobiecki, Rafał: Historici a historická politika. Tamtéž, s. 27-41. 


\section{The idea of the Maffia as a state-forming component in the collective memory of interwar Czechoslovak society}

Academic historical works that examine the activities of the local anti-Austrian resistance and the so-called Maffia usually focus on events during the First World War. However, this study looks at issues connected with the Maffia's 'second life'. The origin of the name goes back to the second half of the 19th century and the arguments over the 'Manuscript', when this name was given to the group of people around T.G. Masaryk, and was used again in 1918 as a symbol of the local antiAustrian resistance. At the same time, its importance in relation to President Masaryk remained unchanged. During the first half of the 1920s, the membership base of the Maffia was identified, with the number of people belonging to the Maffia totalling around 200. The majority were from the middle and upper classes (often representatives of the national political scene), who agreed to cooperate with those in exile during the war. In terms of nationality, they came almost exclusively from Czech society. After the war, the Maffia enjoyed the status of an influential institution with significant moral credit, respected by the majority of the Czech public. Emphasizing the cooperation between the foreign anti-Austrian resistance and the local resistance, represented by the Maffia, provided the leading elite of the young republic in the first postwar years with an important argument to justify and defend the organisation of the new state. At the same time, this enabled them to put forward a single, dominant interpretation of the past, which could help to create a collective memory and identity for its fellow citizens, and establish new state traditions which could provide them with political-historical legitimacy. 
